\title{
招待講演 産婦人科領域における鍼麻酔手術の成績
}

飛松源治

私は，4年ほど前に花谷先生と一緒に中国へ鍼 麻酔の学習に行ってきました。

産科の麻酔は，薬物に対して抵抗が弱くなって いる母と子が相手であるため，常に問題になって います。それで，帝王切開分婏に対する応用を， 主にして，素晴しい効果をみています。

昨年，訪日された中国医療代表団の人の話によ ると，その症例は，200万を突破したとのととで す。中華医学雑誌でも，帝王切開への応用例を， 数百例について報告しており，それも，10数年の むのです。

私共は，遅ればせですが，日本の何処でも，誰 にでも，直ちに，安全に，平易にできるものを， 目標として研究しつづけました。日常の忙しい診 療の中でする研究ですから限度があって, やっと 目鼻がついた段階です。本日，折角お招きを頂き ましたので，そのあらましを報告いたします。

だいたい。痛みというのは，客観的に測るとと が難しく，その研究は感覚のなかでも，いちばん 難しいすのです。しかし，治療にあたる人は絶対 それを除かなりればならない重要な問題です。そ の分類はいろいろ試みられていますが，鍼䏫酔を 行なって感じたことは，それを大きく，外科的な あのと, 内科的な痛みに分けられるということで す。

外科的な痛みは，損傷によって起り，内科的な ものは, 臟器や深組織の異常機能によってみられ るあのです。言いかえれば，鍼の鎮痛作用を外科 的な帝王切開分婏に対しては麻酔法として，また 内科的な産痛には鎮痛法として用いるのです。

お産の苦しみは，誰もが経験し，それはお産が 終れば直ちになくなります。鐵麻酔手術の映画は すでに見られたと思いますので，今日は減痛分婏 のフィルムをもってきました。お産に対する鍼麻 酔は, 赤羽幸兵衛先生が20数年前に皮内鍼で行な い，その直後に中国の本であ紹介されています。
薬物麻酔ですと，人体の生理現象のうち手術中 に必要なむのも不必要なものも全部，除いてしま い，全身的に局所的に植物人間にする結果になり ます。咉画の場面で，鍼麻醉前は，ずっと痛みつ づけていたのが，たいへん楽そうになりました。 経穴に刺した鍼に対する電気刺激の 頻度は，約 160 , 脈搏の $2 \sim 2.5$ 倍をとればよいと思います。 治療には，病人の脈の数ぐらいを用いています。

鍼を刺す順序は，痛む場所の遠くから始め，乙 の場合，三陰交，内側麻酔点，次いで，腰の次 䯘，さいごに下腹壁の子宮穴です。産痛を除くた めに，硬膜外麻酔や，全身麻酔などの薬物麻酔を 行ないますと，怒嘖ができなくなり，分婏は延び て，母子と屯に不利になります。また，子宮の収 縮力屯減弱して, 分婏後に弛緩性の出血が起りや すくなりますが，鍼麻酔では，そのような心配は ありません。生れ出た赤ちゃんの皮膚の色をごら ん下さい。たいへんよい色をして泣いています。

全身麻酔では，寝とぼけた子が生れて，呼吸を しないで困ったりします。お母さんす富士山の頂 上にやっとたどり着いたといいますか，人間の一 大事業を完成した喜びに，浸っているようです。

鍼麻酔というと，誰であ中国のものと思いま す。2,000 年来の同じ 医学の原典をむっている日 本之中国で，今から約20年前，全く独立して鍼麻 酔を発見しました。

日本では，赤羽先生の皮内鍼減痛分婏にヒント を得た大阪の開業医さんが，それを使って人工妊 娠中絶に成功しました。中国では，その後も研究 をつづけて，今では，脳，肺，心藏の手術にまで 用いられるようになっています。そのように，私 ら日本人にも鍼麻酔についての先覚者がおり，乙 の研究の発展に，民族的な使命感を意識いたしま す。かりに，日本で鍼麻酔手術ができないという ことであれば，先覚者に対して，面目が立ちませ ん。それに，なんといって屯，3週間，中国で私 
を通じて，日本の皆さんに伝えて，日中両国人民 の友情の証しにしたいと，つきっきりで一生懸命 教えてくれた友人たちに，病人や家族の喜びを伝 えたいと思います。

都立豊島病院の針麻酔のいちばん目玉は帝王切 開です。その外, 卵管結紮不妊手術, 初期妊娠人 工中絶，てまでましたものに応用しています。す でに，76例の経験を重ねましたが，57症例でまと めたものについてお話します。

やり易い症例だけやっているのではないか, 患 者への説得む，かなり時間をかけているから，成 功しているのではないかと，尋ねられますが，38 \%は急に行なったものです。早い人は鍼を刺して 5 分で始めます。手術はそのように緊急にする場 合と，母子の危険を予測して，予防的に行なう場 合がありますが，その比は $1 ： 2$ です。したがっ て, 何時, 何処でも, 直ぐにの 3 つの条件は, む う整ったと思います。誰にでも，平易にが，問題 になります。それが達成されなければ，世間から よい評価を得ることはできません。

手術中の痛み, また，お産の痛みの程度を記録 として残し，検討すれば問題点がはっきり捕えら れ，解決法む見つかります。予測法としては，痛 みで起る交感神経の興奮度を, 脈の速さ, 呼吸の 頻度, 瞳孔の散大度, 涙管の収縮による㴟の出か た，などがあります。しかし，それらを忙しい手 術場で, また, 設備が十分でない大衆病院で測定 するのは容易でありません。そこで私たちは記録 が簡単な，手術痛スコアを採点しています。57例 全部の平均は $4.2 \pm 2.2$ 点です。このでろは 2 点前 後です。 2 点というのは, ちょっと, しかめ顔, 拳を握ったり，軽くうめく程度です。このような スコア採点を薬物麻酔の症例で記録してみると, 決して 0 点ではありません。仮りに，手術中は静 かでも, 病室に帰えってからうなり続けます。

中国では，ずい分ていねいに教えてくれたので すが, 私らの理解が不十分で，初めのとろは5.9 土2.8点で，患者はかなり苦しそうでした。それ であ, 術後の経過が非常によかったので, 患者さ んは喜び，私たちを励ましてくれました。

手術の途中, ぞんな操作で苦しめるのか, 注意 してみますと, 子供の頭が出る時に, $3.4 \pm 1.8$ 点
でした。これも改善されて, 最近では 2 点ぐらい です。次いで, 皮庵の縫合, 特に恥骨結合部の付 近がかなり痛そうです。

動物の鍼麻酔を研究している人の話では, 鼻の 頭, 耳の先, 生殖器, 外陰部などはかかりにくい そうです。

鍼麻酔帝王切開の臨床分析をやってみました。 患者は21 39才の間ですが, 20才代でも40才近く であ効果に影響がありません。初産よりは, 経産 の人がよい結果をみせています。それも自然分婏 と，帝王切開分婏の間に差をみません。陣痛の有 無も関係ありません。前に帝王切開を受けた人は 3 人に 1 人癒着を起しているのですが, 癒着があ る場合, 多少スコアが悪くなります。

鍼麻酔のニュースが，日本に伝わったてろ，一 部の人にあれは毛沢東語録を厳しく読ませて, 辛 抱させているのだろうと, ささやかれていました 私あ初めのてろ,ずい分励んだものですが，決定 的なあのではありませんでした。しかしてれをや ると患者ばかりか, 術者の心もおちつきます。

帝王切開以外の開腹手術を受けた人々について 調べてみますと，それらの群は手術を恐れている せいか，少し劣っていました。母体が命にかかわ る重症な病気で, 救急の帝王切開をする場合は, よい点数を示しており，鍼麻酔は患者自身がやら なければならないと自覚するととが，たいせつな ようです。

必要な人に, よい効果を現わすのは鍼麻酔に限 りません。熱のない人にアスピリンを与えても, 下熱しないし, 痛みがない人に, 痛みどめを与え てむ，副作用を現わすだけです。麻酔がかかるま でに, 少し時間を必要とするのが難点だという人 むいます。腰椎麻酔で手術開始まで, 平均15分,

鍼麻酔で26分ですから，そんなに問題になりませ ん。子供がでるまで, 12 分, 全手術の時間は約50 分余です。出血量は, 平均 $344 \mathrm{ml}$ で, 他の薬物麻 酔より少なく, 特に生れでた赤ちゃんが元気なと とは，たいへん嬉しいととです。患者は病室へす ごると, すぐに飲みあのをとり, 夕食あ食べます 2 日目からは歩き, お乳の出むよく 9 日目でろに は元気で退院してゆきます。

鍼麻㜞帝王切開の子は, 育ちがよい, 頭がよい 
と，母親たちがいうので，うちの小児科の先生に 調へててらいました。

140項目余について，生れて1年ごろにテスト してみますと，腰椎麻酔の子よりすぐれておりま した。しかし，自然分婏児と同じですから，自然 分婏こそ最良のあのなのでしょう。

銊麻䣲は, 患者の正常な神経生理機能のもとで 鍼の刺激と、メスの刺激を争わせるのですから、そ れら 3 つの面加ら研究を進める必要があります。 同時にいろいろやったのでは，何がよい役割をは たしたのか分りませんので，今のとてろ，経穴を 一定にして行なっています。

私らが用いている経穴を，西洋医学流倹討し てみましょう。

腹を切るのに，なぜ足に鍼を刺すのかというこ とに，2つの理由を考えています。1つは，神経 の皮店分節支配です。人間は，何万年かの間に， 立ち姿になったので，一見，不規則な皮庸分節を 示しておりますが，四つんばいの昔の姿勢にしま すと，横割りの規則的なすのになります。私たち あ胎児の時は手足もお玉じゃくしや，魚と同じよ うに，首あとや下腹部あたりの小さい突起でし

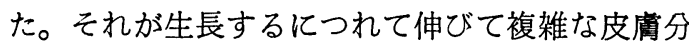
節をあった長い手足になったのです。内臓や筋肉 にあそれぞれ内臟分節，筋分節がありますが，解 剖学的な位置では，無関係のようにみえます。こ れす胎児のころはそれぞれ同じ場所に発生したの ですが，体の生長につれて，不規則にみえるとい うだけのことです。ですから脳，歯，胸の手術の

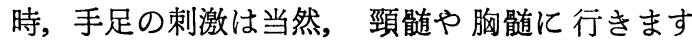
し，足に銊を刺せば，仙喊や腰髄に伝えられ，手 術や，減痛分婏ができるのです。

あう 1 つは，手足の経穴の銊感は強烈であると いうことです。すでに申しましたように，細い手 足にたくさんの皮佣分節支配神経と筋肉分節支配 神経が，総合配線管のように集中しております。 ですから頭，頸，胸，腹部の経穴を刺激するより も，強い銊感が，広範囲な神経中枢に伝えられま す。また，手足は複雑な動作をする所なので，筋 肉, 筋膜, 腱, 関節周辺など, 多くの深部感覚受 容器が, 密着分布しています。したがって，てれ らの部位を銊刺激するてとは，たいへん効果む大
きいのです。

次に，鍼感と鍼麻醉の効果の関係について話し ましょう。映画でみられたように，鍼麻醉減痛分 婏をしてみますと，鍼を刺しただけでも一定の効 果がみられます。しかし痛みが激しい時は，その 効果は長くつづきません。銊に通電刺激をすると 効果は持続しますが，それを切ると間むなく再び

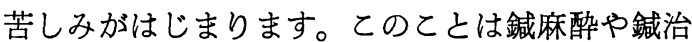
療で，鍼感がきわめてたいせつであるてとを教え ます。

映画で見せた人の苦し みの度合いは，スコアを 採点すると 9 点です。それが鐵麻醉すると急に 1 ～2 点に下がります。その前は陣痛が休む，間歇 期でさえ苦しんでいたのが，銊麻䣲の後は，うと うと眠りさえしていました。後で本人の感想を聞 くと, あの楽さは砂漠のオアシスのほっとした感 じと表現されました。

鍼麻醉と鍼治療は，古くて新らしいもの，中国 のもので日本のもの，東洋医学と西洋医学が結合 したすのです。その生いたち加みてす，私たち は日本や中国の友人たちと力を合わせて，進んで この面で世界の先頭にたち，人類のために貢献し なければならないと思っています。初歩的な段階 にある私たちの銊麻酔について，みなさんの貴重 なご批判とで意見がいただけれい゙嬉しいと思いま す。

で静啰のあがとうございました。 